\title{
Faktor-faktor yang Mempengaruhi Perilaku Merokok Pada Remaja Putera Kelas XI di SMK Sasabila Kota Jambi
}

\author{
Liza $^{1}$, Fitri Aulia ${ }^{2}$ Erika $^{3}$ \\ Akademi Kebidanan Budi Mulia Jambi ${ }^{1,2,3}$
}

\section{A B S T R A K}

Informasi Artikel :

Diterima :02 November 2021

Direvisi : 09 November 2021

Disetujui : 20 Desember 2021

Diterbitkan : 30 Desember 2021

*Korespondensi Penulis : Lizaboulqiah041290@gmail.com
Dalam setiap kepulan asap rokok terkandung \pm 4000 racun kimia berbahaya dan 43 diantaranya bersifat karsinogenik (merangsang tumbuhnya kanker). Penelitian di Amerika Serikat yang melibatkan 6813 pria, menunjukkan hasil bahwa $50 \%$ perokok berat meninggal pada usia 47,5 th dan $50 \%$ perokok sedang meninggal pada usia 56 tahun.. Adapun tujuan penelitian ini adalah Untuk Mengetahui ada nya hubungan antara perilaku merokok dengan pengaruh orangtua, pengaruh teman dan faktor iklan. Dan desain penelitian yang digunakan adalah survey analitik dengan pendekatan Cross Sectional. Pengambilan sampel di lakukan secara Total Sampling yaitu seluruh populasi dijadikan sampel. Analisa data secara univariat dilakukan untuk mengetahui distribusi frekuensi dan persentase dari variabel perilaku merokok pada remaja putera, pengaruh orangtua, pengaruh teman dan faktor iklan, sedangkan analisis data secara bivariat ini dilakukan untuk mengetahui hubungan antara variabel independen dan variabel dependen di analisis dengan uji statistikChi-Squer dimana $\alpha=0,05$ dan dengan batas kemaknaan bila $\mathrm{p}$ value $\leq 0,05$ artinya ada hubungan yang bermakna dan bila $p$ value $>0,05$ tidak bermakna. Dari hasil univariat menunjukan responden merokok 12 responden $(34,4 \%)$ dan tidak merokok 23 responden $(65,7 \%)$, pengaruh orangtua yang baik 21 responden $(60,0 \%)$ dan tidak baik 14 responden $(40,0 \%)$, pengaruh teman yang baik 16 responden $(45,7 \%)$ dan yang tidak baik 19 responden $(54,3 \%)$, responden merokok karena faktor iklan 11 responden $(31,4 \%)$ dan tidak 24 responden $(68,6 \%)$, dan hasil bivariat menunjukan pengaruh orangtua baik yaitu 3 responden $(13,6 \%)$ tidak yaitu 9 responden $(69,2 \%)$, pengaruh teman baik yaitu 10 responden $(62,5 \%)$ dan tidak yaitu 2 responden $(10,5 \%)$, faktor iklan yang ya yaitu 8 responden $(72,7 \%)$ dan tidak yaitu 4 responden (16,7\%). Orangtua harus lebih memperhatikan perkembangan anak, terutama remaja putera terhadap kejadian perilaku merokok pada remaja putera yang semakin memarak terutama dikalangan anak sekolah pertama (SMK).

Kata Kunci : Perilaku Merokok Pada Remaja Putera 
of the variable smoking behavior in adolescent son, the influence of parents, friends and the influence of advertising factor, while the bivariate analysis of the data was conducted to determine the relationship between the independent variables and the dependent variable in the analysis to test statistikChi-squer where $\alpha=0.05$ and the limit of significance when the $p$ value $\leq 0.05$ means there is a meaningful relationship and if the $p$ value $>0.05$ is not significant . From the univariate results showed respondents smoking 12 respondents (34.4\%) and non-smoking 23 respondents $(65.7 \%)$, the effect of a good parent 21 respondents $(60.0 \%)$ and well 14 respondents $(40.0 \%)$, the influence of a good friend 16 respondents (45.7\%) and that is not good 19 respondents (54.3\%), respondents smoking because of advertising 11 respondents $(31.4 \%)$ and 24 respondents $(68.6 \%)$, and bivariate results showed the influence of both parents is 3 respondents (13.6\%) was not that 9 respondents (69.2\%), the effect of a good friend of 10 respondents (62.5\%) and there are 2 respondents (10.5\%), yes advertisements factor is 8 respondents $(72.7 \%)$ and not that 4 respondents (16.7\%). Parents should pay more attention to the development of children, especially teenage son on the incidence of smoking behavior in adolescent son who is getting flare up, especially among school children(SMK).

Keywords :Smoking behavior in Adolescent Son Classs XI

\section{PENDAHULUAN}

Remaja merupakan suatu masa kehidupan individu dimana terjadi eksplorasi psikologis untuk menemukan identitas diri.Pada masa transisi dri masa anak-anak ke masa ramaja, individu mulai mengembangkan cirri-ciri abstrak dan konsep diri menjadi lebih berbeda. Remaja mulai memandang diri dengan penilaian dan standar pribadi, interpretasi perbanndingan sosial (Eny Kusmiran, 2012)

Merokok merupakan masalah yang terus berkembang dan belum dapat ditemukan solusinya di Indonesia sampai saat ini.Merokok dapat menyebabkan hipertensi akibat zat-zat kimia yang terkandung di dalam tembakau yang dapat merusak lapisan dalam dinding arteri, sehingga arteri lebih rentan terjadi penumpukan pelak (arteriosklerosis). Hal ini terutama disebabkan oleh nikotin yang dapat merangsang saraf simpati sehingga memacu kerja jantung lebih keras dan menyebabkan penyempitan pembuluh darah, serta peran karbon monoksida yang dapat menggantikan oksigen dalam darah dan memaksa jantung memenuhi kebutuhan oksigen tubuh

Hasil studi menunjukkan bahwa perokok berat telah memulai kebiasaan merokok sejak berusia belasan tahun, dan hampir tidak ada perokok berat yang baru memulai merokok pada saat dewasa. Karena itulah, masa remaja sering kali dianggap masa kritis yang menentukan apakah nantinya menjadi perokok atau bukan (Abdul Syair, 2009).

Survei Riset Kesehatan Dasar (Riskesdas) tahun 2013 yang dirilis Badan Penelitian dan Pengembangan Kesehatan, Kementerian Kesehatan, Republik Indonesia menyebutkan, bahwa konsumsi rokok pada penduduk kelas menengah kebawah rata-rata mencapai 12 batang per hari atau sekitar 360 batang dalam sebulan. Bila diasumsikan harga sebatang rokok sebesar Rp500-, itu artinya uang yang dihabiskan untuk membeli rokok oleh penduduk kelas menengah kebawah mencapai Rp180.000,- dalam sebulan 
Celakanya, hasil Riskesdas tahun 2013 juga menunjukkan, konsumsi rokok pada anakanak, yakni penduduk kelompok usia 10-14 tahun, juga sangat tinggi. Dimana konsumsi rokok pada kelompok usia ini mencapai sekitar 8 batang per hari atau 240 batang dalam sebulan. Itu artinya, dalam sebulan "anak-anak" perokok di negeri ini menghabiskan uang sebesar Rp120.000,untuk membeli rokok (Kadir Ruslan, 2011).

Menurut Lewin (2005), Faktor yang mempengaruhi merokok pada remaja adalah faktor lingkungan dan individu. Laventhal mengatakan bahwa merokok pada tahap awal dilakukan karena ajakan teman-teman (46\%), anggota keluarga (bukan orangtua) (23\%) dan orangtua (14\%).

Berdasarkan kejadian merokok di usia muda (15-18 tahun) sudah menunjukkan angka yang berarti, yakni 13,62 persen. Jumlah perokok di Indonesia menempati urutan terbesar keempat dunia dengan kekerapannya sekitar $60 \%$ pada laki-laki dan $4 \%$ pada perempuan yang berumur lebih dari 15 tahun (Burhan, 2004). Kondisi yang lebih memprihatinkan lagi, bahwa kebiasaan merokok justru dimulai pada usia yang sangat muda (Matua Harahap, 2004)

Di Kota Jambi, berdasarkan Laporan bidang Promosi kesehatan dinkes Kesehatan Kota Jambi, belum ada laporan pravensi remaja yang merokok

Berdasarkan dari uraian di atas penulis tertarik untuk penelitian dengan judul "Faktor-Faktor Yang Mempengaruhi Perilaku Merokok Pada Remaja Putera Kelas XI Di SMK SALSABILA Kota Jambi Tahun 2021"

\section{METODE PENELITIAN}

Penelitian ini menggunakan metode Survey Analitik yaitu survey atau penelitian yang mencoba menggali bagaimana dan mengapa fenomena kesehatan itu terjadi, dengan pendekatan Cross Sectional dimana data yang menyangkut variabel bebas atau resiko dan variabel terikat atau variabel akibat, dikumpulkan dalam waktu yang bersamaan (Notoatmodjo, 2010).

Desain penelitian yang digunakan dalam penelitian ini adalah deskriptif korelasi yang bertujuan untuk menjelaskan hubungan antara variable-variabel baik bebas maupun terikat. Penelitian ini dilakukan dengan pendekatan cross sectional, yaitu suatu penelitian di mana variable-variabel yang termasuk faktor risiko dan variable-variabel yang termasuk efek diobservasi sekaligus pada waktu yang sama (Notoatmodjo, 2005).

Populasi adalah semua Remaja Putera Kelas XI Di SMK SalsabilaKota Jambi Tahun 2021. Pengambilan sampel dilakukan dengan menggunakan metode non random teknik "accidental sampling" yaitu sampel diambil dari 35 responden yang ada sewaktu dilakukan penelitian Kelas XI di SMK Salsabila Kota Jambi Tahun 2021.

Analisis ini dilakukan untuk mengetahui hubungan antara variabel independen (Faktor Iklan, Pengaruh Orangtua dan Pengaruh Teman) dengan variabel dependen (Perilaku Merokok Pada Remaja Putera Kelas XI) SMK SalsabilaKota Jambi Tahun 2021 yang dianalisis dengan uji statistic Chi-Square dan mengunakan komputerisasi dengan tingkat kemaknaan $\alpha=0,05$.

Analisa ini dilakukan untuk melihat hubungan (kolerasi) antara variabel independen dengan variabel dependen.

Keputusan dari pengujian Chi-Square:

1. Jika $p$ value $\leq \alpha$; Ho ditolak dan $\mathrm{Ha}$ diterima yang berarti ada hubungan antara variabel independen dengan variabel dependen.

2. Jika $p$ value $\leq \alpha$; Ho diterima dan $\mathrm{Ha}$ ditolak yang berarti tidak ada hubungan antara variabel independen dengan variabel dependen. 


\section{HASIL PENELITIAN}

\section{A. Analisa Univariat}

\section{Perilaku merokok pada remaja putera kelas XI}

Pada penelitian ini perilaku merokok pada remaja putera kelas XI SMK Salsabila Kota JambiTahun 2021, dikelompokkan menjadi 2 kategori yaitu : merokok dan tidak merokok, untuk lebih jelasnya dapat dilihat pada tabel 1 dibawah ini.

Tabel 1 Distribusi Frekuensi Responden Berdasarkan Perilaku Merokok Pada Remaja Putera Kelas XI Di SMK Salsabila Tahun 2021

\begin{tabular}{llcc}
\hline No & $\begin{array}{c}\text { Remaja } \\
\text { Merokok }\end{array}$ & F & $\begin{array}{c}\text { Persentase } \\
\mathbf{( \% )}\end{array}$ \\
\hline 1 & Merokok & 12 & $34,3 \%$ \\
\hline 2 & $\begin{array}{l}\text { Tidak } \\
\text { Merokok }\end{array}$ & 23 & $65,7 \%$ \\
\hline & Jumlah & 35 & $100 \%$ \\
\hline
\end{tabular}

Tabel 1 diatas dapat diketahui bahwa dari 35 responden ysng merokok mempunyai proporsi lebih kecil yaitu 12 responden $(34,3 \%)$, dibandingkan responden yang tidak merokok yaitu 24 responden $(65,7 \%)$.

\section{Faktor Iklan}

Pada penelitian ini faktor iklan di kelompokkan menjadi 2 kategori yaitu ya, (bila ada faktor iklan) terhadap perilaku merokok remaja putera kelas XI di SMKSalsabila Kota Jambi Tahun 2014 dan tidak, (bila tidak ada faktro iklan), untuk lebih jelasnya dapat dilihat pada tabel di bawah ini :

\section{Tabel 2 Distribusi Frekuensi Responden} Berdasarkan Faktor Iklan Di SMK Yayasan Bakti Kota Prabumulih Tahun 2014

\begin{tabular}{llcc}
\hline No & Faktor Iklan & F & $\begin{array}{c}\text { Persentase } \\
(\%)\end{array}$ \\
\hline 1 & Ya & 11 & $31,4 \%$ \\
\hline 2 & Tidak & 24 & $68,6 \%$ \\
\hline
\end{tabular}

Jumlah

$35 \quad 100 \%$

Tabel 2 Diatas dapat diketahui bahwa proporsi responden menjawab perilaku merokok pada remaja karena faktor iklan lebih kecil yaitu 11 responden $(31,4 \%)$, dibandingkan dengan yang tidak karena faktor iklan yaitu 24 responden $(68,6 \%)$.

\section{Pengaruh Orangtua}

Pada penelitian ini pengaruh orangtua dikelompokkan menjadi 2 kategori yaitu ya, (bila ada pengaruh orangtua) dan tidak, (bila tidak ada pengaruh orangtua), untuk lebih jelasnya dapat dilihat pada tabel 3 di bawah ini :

\section{Tabel 3 Distribusi Frekuensi Responden Berdasarkan Pengaruh Orang Tua Pada Remaja Putera Kelas XI Di SMK Salsabila Tahun 2021}

\begin{tabular}{llcc}
\hline No & $\begin{array}{c}\text { Pengaruh } \\
\text { Orang Tua }\end{array}$ & F & $\begin{array}{c}\text { Persentase } \\
(\mathbf{\%})\end{array}$ \\
\hline 1 & Ya & 22 & $62,9 \%$ \\
\hline 2 & Tidak & 13 & $37,1 \%$ \\
\hline & Jumlah & 35 & $100 \%$ \\
\hline
\end{tabular}

Tabel 3 Diatas diketahui bahwa proporsi responden menjawab perilaku merokok pada remaja karena pengaruh orangtua lebih besar yaitu sebanyak 22 responden $(62,9 \%)$, dibandingkan tidak karena pengaruh orangtua yaitu sebanyak 13 responden $(37,1 \%)$.

\section{Pengaruh Teman}

Pada penelitian ini pengaruh teman dikelompokkan menjadi 2 kategori yaitu ya, (bila ada pengaruh teman) dan tidak (bila tidak ada pengaruh teman), untuk lebih jelasnya dapat dilihat pada tabel 4 dibawah ini:

Tabel 4 Distribusi Frekuensi Responden Berdasarkan Pengaruh Teman Di SMK Yayasan Bakti Kota Prabumulih Tahun 2014 


\begin{tabular}{llcc}
\hline \hline No & Pengaruh Teman & F & $\begin{array}{c}\text { Persentase } \\
(\mathbf{\%})\end{array}$ \\
\hline 1 & Ya & 16 & $45,7 \%$ \\
\hline 2 & Tidak & 19 & $54,3 \%$ \\
\hline & Jumlah & 35 & $100 \%$ \\
\hline
\end{tabular}

merokok pada remaja karena pengaruh teman lebih lebih kecil yaitu 16 responden $(45,7 \%)$ dibandingkan tidak karena pengaruh teman yaitu 19 responden $(54,3 \%)$.

Tabel 4 Diatas diatas diketahui bahwa proporsi responden yang menjawab prilaku

\section{Analisis Bivariat}

Analisis ini dilakukan untuk mengetahui hubungan antara variabel independen (pengaruh orangtua, pengaruh teman dan faktor iklan) dengan variabel dependen (perilaku merokok pada remaja putera kelas XI), dengan batas kemaknaan $\mathrm{p}$ value $=0,05$,uji statistik yang dilakukan adalah uji chi-square dengan menggunakan program komputerisasi SPSS.

\section{Hubungan Faktor Iklan dengan Perilaku Merokok Pada Remaja}

Penelitian ini dilakukan pada 35 responden dimana faktor iklan dibagi menjadi 2 kategori yaitu ya, (bila ada faktor iklan) dan tidak (bila tidak ada faktor iklan), sedangkan perilaku merokok pada remaja putera kelas XI dibagi menjadi 2 kategori yaitu merokok dan tidak meroko, untuk lebih lanjut dapat dilihat pada tabel di bawah ini :

Tabel 4 Hubungan Antara Faktor Iklan dengan Perilaku Merokok PadaRemaja Putera Kelas XI Di SMK

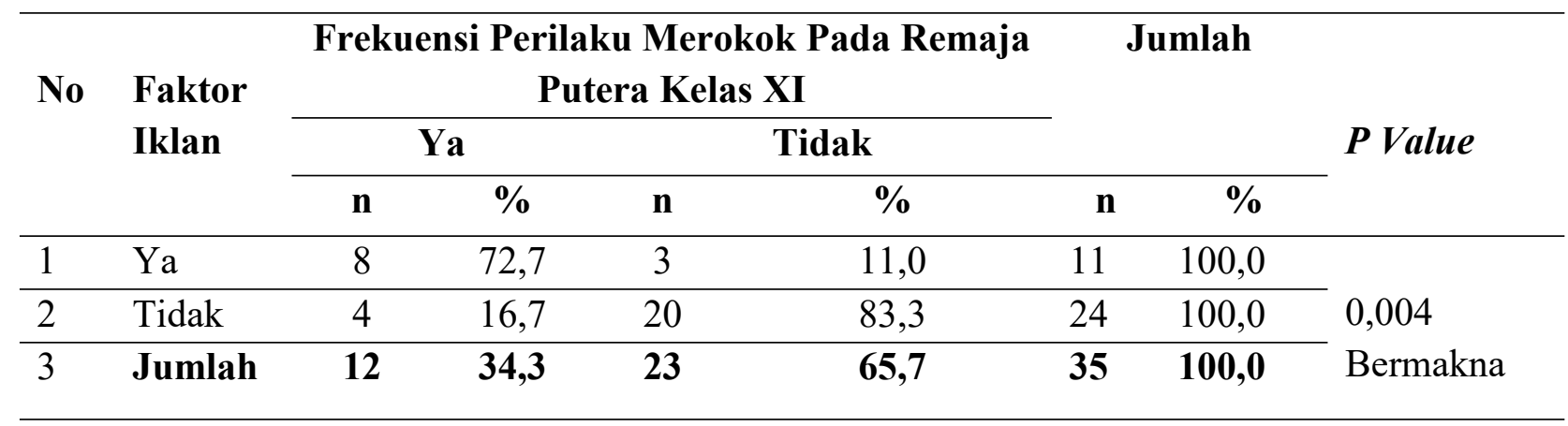

Berdasarkan tabel diatas dapat diketahui dari 11 responden yang merokok karena faktor iklan yaitu sebanyak 8 responden (72,7\%) dan merokok tidak karena faktor iklan sebanyak 4 responden (16,7\%). Dari hasil uji statistik Chi-square $\rho$ value $=0.004<$ a 0,05 . Hal ini menunjukkan ada hubungan yang bermakna antarafaktor iklan dengan perilaku merokok pada remaja putera kelas XI, sehingga hipotesis ada hubungan yang bermakna antara faktor iklan dan perilaku merokok pada remaja putera kelas XI terbukti secara statistik.

\section{Hubungan Pengaruh Orangtua dengan Remaja Putera Kelas XI}

Penelitian ini dilakukan pada 35 responden dimana pengaruh orangtua dibagi menjadi 2 kategori yaitu ya (bila ada pengaruh orangtua) dan tidak (bila tidak ada pengaruh orangtua) sedangkan perilaku merokok pada remaja putera kelas XI dibagi menjadi 2 kategori yaitu merokok dan tidak merokok, untuk lebih jelasnya dapat dilihat pada tabel dibawah ini : 


\section{Tabel 4 Hubungan Antara Pengaruh Orangtua dengan Perilaku Merokok Pada Remaja Putera Kelas XI Di SMK Salsabila Kota JambiTahun 2021}

\begin{tabular}{|c|c|c|c|c|c|c|c|c|}
\hline \multirow[t]{3}{*}{ No } & \multirow[t]{3}{*}{ Pengaruh Orangtua } & \multicolumn{4}{|c|}{$\begin{array}{c}\text { Frekuensi Perilaku } \\
\text { Merokok Pada Remaja } \\
\text { Putera Kelas XI } \\
\end{array}$} & \multirow{2}{*}{\multicolumn{2}{|c|}{ Jumlah }} & \multirow[t]{3}{*}{$P$ Value } \\
\hline & & \multicolumn{2}{|c|}{$\mathbf{Y a}$} & \multicolumn{2}{|c|}{ Tidak } & & & \\
\hline & & n & $\%$ & $\mathbf{n}$ & $\%$ & $\mathbf{n}$ & $\%$ & \\
\hline 1 & $\mathrm{Ya}$ & 3 & 13,6 & 19 & 86,4 & 22 & 100,0 & \\
\hline 2 & Tidak & 9 & 69,2 & 4 & 30,8 & 13 & 100,0 & 0,003 \\
\hline 3 & Jumlah & 12 & 34,3 & 23 & 65,7 & 35 & 100,0 & Bermakna \\
\hline
\end{tabular}

Berdasarkan tabel diatas diketahui dari 12 responden yang merokok karena pengaruh orangtua sebanyak 3 responden $(13,6 \%)$ dan merokok tetapi tidak karena pengaruh orangtua sebanyak 9 responden (69,2\%). Dari hasil uji statistik Chi-square $\rho$ value $=0.003<$ a 0,05 . Hal ini menunjukkan ada hubungan yang bermakna antarapengaruh orangtua dengan perilaku merokok pada remaja putera kelas XI , sehingga hipotesis ada hubungan yang bermakna antara pengaruh orangtua dan perilaku merokok pada remaja putera kelas XI terbukti secara statistik.

\section{PEMBAHASAN}

Penelitian ini dilakukan di SMK SalsabilaKota Jambi pada tanggal 13 Maret 2021. Metode penelitian yang di gunakan survey analitik dengan pendekatan cross sectional,di mana variabel independen (faktor iklan, pengaruh orangtua dan pengaruh teman) dan variabel dependen perilaku merokok pada remaja putera kelas XI di kumpulkan dalam waktu yang bersamaan, populasi dalam penelitian ini semua remaja putera kelas XI yang ada saat dilakukan penelitian di SMK SalsabilaKota Jambi, yang berjumalh 35 orang.Selanjutnya data yang telah dikumpulkan, diolah dan di lakukan analisis data univariat dan bivariat dengan menggunakan system komputerisasi, sehingga pada analisis univariat di dapatkan daftar distribusi frekuensi dari masing-masing variabel.sedangkan pada analisis bivariat dilakukan dengan uji chi-square dengan tingkat kemaknaan $\alpha=0,05$

a.Perilaku Merokok Pada Remaja Putera Kelas XI
Pada penelitian perilaku merokok pada remaja putera kelas XI diSMK SalsabilaKota Jambi Tahun 2021 dikategorikan menjadi 2 kategori yaitu merokok dan tidak merokok.Hasil analisis univariat dari 35 responden, 12 responden $(34,3 \%)$ berperilaku merokok, dan 23 responden (65,7\%) tidak merokok. Sesuai dengan penelitian Albar (2009), bahwa penyebab perokok remaja adalah keluarga yang broken home, dimana orangtua tidak begitu memperhatikan anakanaknya.

\section{a. Faktor Iklan}

Analisa Univariat menunjukkan, bahwa proporsi responden menjawab perilaku merokok pada remaja karena faktor iklan lebih kecil yaitu 11 responden (31,4\%) dibandingkan dengan responden yang tidak karena faktor iklan 24 responden $(68,6 \%)$.Hasil uji statistik menganalisa ada hubungan yang bermakna antara faktor iklan dan perilaku merokok pada remaja putera kelas XI di SMK SalsabilaKota Jambi Tahun 2021 ( $\alpha$ p value $0,004<\alpha=0,005$ ). 
Hasil peneliti ini sama dengan penelitian Arina Uswatun Hasanah, Sulastri, (2011), bahwa ada hubungan bermakna anatara iklan rokok dengan perilaku merokok pada siswa laki-laki di Madrasah Aliyah Negeri 2 Boyolali dengan tingkat bermakna 0,532 . Hasil penelitian in sama dengan pendapat Albar (2009), bahwa dengan melihat iklan di media massa dan elektronik yang menyimpulkan gambaran bahwa perokok adalah lambang kejantanan atau glamour, membuat remaja seringkali terpicu untuk mengikuti perilaku seperti yang ada pada iklan tersebut.

\section{KESIMPULAN}

Dari hasil penelitian di SMK SalsabilaKota Jambi Tahun 2021 diketahui faktor-faktor yang mempengaruhi perilaku merokok pada remaja putera kelas XI, dapat disimpulkan sebagai berikut : Proporsi lebih kecil yaitu 12 responden (34,3\%), dibandingkan responden yang tidak merokok yaitu 23 responden (65,7\%). Proporsi responden menjawab perilaku merokok pada remaja karena faktor iklan lebih kecil yaitu 11 responden $(31,4 \%)$, dibandingkan dengan yang tidak karena faktor iklan yaitu 24 responden (68,6\%).Ada hubungan yang bermakna antara faktor iklan dan frekuensi perilaku merokok pada remaja putera kelas XI, dimana karena $p$ value 0,004 . Ada hubungan yang bermakna antara pengaruh orangtua dan frekuensi perilaku merokok pada remaja putera kelas XI, dimana karena $\mathrm{p}$ value 0,003 .

\section{DAFTAR PUSTAKA}

Abdulateef, Darya Saeed., Ali, Azheen Jamil., Abdulateef, Darwan Saeed dan Mohesh, Glad. 2016. Smoking Knowledge, Attitude, and Practices Among Health Care Professionals from Sulaymaniyah City/Iraq. Freedom to Researh. Libertas Academica.
Ilyati, Syarfa. 2015. Gambaran Tingkat Pengetahuan, Perilaku Merokok dan Nikotin Dependen Mahasiswa UIN Syarif Hidayatullah Jakarta. Skripsi.Fakultas Kedokteran dan Ilmu Kesehatan, Universitas Islam Negeri Syarif Hidayatullah Jakarta.

Izzati, Nurul., Azlina, Nor., Iza, Nor dan Mainul. 2016. Knowledge, Attitude and Practice towards Smoking among International Islamic University Malaysia Kuantan Communities. Department of Biomedical Science.Volume 15 Number 2

Kusumawati, Yuli., dkk. (2015). Model Pemberdayaan Konseling Peer Education Upaya Membentuk Perilaku Berhenti Merokok pada Mahasiswa.Volume 05 No 3, Februari 2015. Diambil dari: publikasiilmiah.ums.ac.id (26 Juli 2021)

Permatasari, N H. 2015.Persepsi Mahasiswa Perokok mengenai Gambar Peringatan Bahaya Merokok pada Kemasan Rokok bagi Mahasiswa Prodi PGSD FKIP Universitas Muhammadiyah Surakarta tahun 2014/2015. Naskah Publikasi. Universitas Muhammadiyah Surakarta.

Putri, R A. 2016. Hubungan Tingkat Stres dengan Tingkat Perilaku Merokok pada Mahasiswa Semester Tujuh di Fakultas Hukum Universitas Muhammadiyah Surakarta. Naskah Publikasi. Universitas Muhammadiyah Surakarta.

Kemenkes. 2017. Pedoman Pengembangan Kawasan Tanpa Rokok. Jakarta: Pusat promosi kesehatan

Nirmala,R.2016.Segudang Bahaya Merokok Terhadap Tubuh http://www.alodokter.com/SegudangBahaya-Merokok-Terhadap-Tubuh-html Notoatmodjo, S. 2010. Metodologi Penelitian Kesehatan. Jakarta: Rineka cipta.

Patonah, Siti, et al.2013 "Hubungan perilaku merokok keluarga di dalam rumah 
dengan kejadian bronchopneumonia pada balita." Asuhan Kesehatan: Jurnal

Ilmiah Ilmu Kebidanan dan

Keperawatan

Sianaga,H.(Ed).2013.Hidup yang

Menyehatkan.Bandung : IPH

Salim, Ardy Darmawan. 2015. Promosi,

Iklan dan Sponsor Rokok Strategi

Perusahaan Mengiring Remaja untuk

Merokok. Volume 17 No 1, Juni 2015.

Diambil dari:

publikasiilmiah.ums.ac.id (26 Juli 2021)

Triyono.2016.Bahaya Rokok Bagi

Remaja.From

http://wskitamandiribk.wordpress.com/

2016/bahaya-rokok-bagi-remaja

WHO. 2015. The Millenium Development

Gols for Health. Jakarta : World

Health Organitation. 